\title{
TRADITIONS AND FOREIGN INFLUENCES: SYSTEMS OF LAW IN CHINA AND JAPAN
}

\author{
Percy R. Luney, Jr.* \\ INTRODUCTION
}

By training, what I know about Chinese law comes from my study of the Japanese legal system. Japan imported several early Chinese legal codes in the seventh and eighth centuries and adapted this law to existing Japanese social and economic conditions. The Chinese Confucian philosophy and system of ethics was introduced to Japan in the fourteenth century. The Japanese and Chinese legal systems adopted Western-style legal codes to foster economic growth and international trade; and, more importantly, both have an underlying foundation of Confucian philosophy. As an outsider to the study of China, my views represent those of a comparativist commenting on his perceptions of foreign influences on the Chinese legal system. These perceptions are based on my readings about Chinese law, my professional study of Japanese law, and the presentation given by Professor Whitmore Gray ("The Soviet Background") at the 1987 Duke Conference on Chinese Civil Law.

Legal reforms in China are generating much debate by Western legal scholars about the future of the Chinese legal system. After the fall of the Gang of Four, the new Chinese Government has sought to strengthen and to improve the stature of the legal system. The goal is a socialist legal system with Chinese characteristics. ${ }^{1}$

The post-Mao leadership views the legal system as an essential element in the economic development process. ${ }^{2}$ Chinese expectations are that a legal system can provide the societal stability necessary for economic

Copyright (C) 1989 by Law and Contemporary Problems

* Associate Professor, North Carolina Central University School of Law; Visiting Professor, Duke University School of Law.

1. Hsia \& Zeldin, Recent Developments in the People's Republic of China, 28 Harv. INT'L L.J. 249 (1987). Deng Xiaoping, China's top leader, stated that "[i]t is necessary to formulate a series of laws, decrees, and regulations to put democracy in the form of a system of laws." Id. at n.l (citing Selected Works of Deng Xiaoping 319 (1983) (translated in FBis, Daily Report: China, Aug. 10, 1983, at K 18).

2. See generally Donahoe, The Promise of Law for the Post-Mao Leadership in China, 41 Stan. L. Rev. $171.85(1988)$. 
modernization. ${ }^{3}$ As China builds its new legal system and looks to foreign models for guidance, the relationship between the legal system, government, and the ruling political party is far from clear. Will the new Chinese legal system be "pluralist" rule of law or "institutionalized" rule by law? Will law protect people's rights from the political party and government or will law strengthen the control and power of the ruling political party and government?

Early Chinese Law-The Confucian Tradition and the Adoption of German Civil LaW

For most of China's history, law, in the Western sense of the word, played a relatively minor role. For over two thousand years, the natural law of Confucian philosophy was adopted by the Chinese Government. Confucian philosophy is a personal and social morality which defines the natural order of things. Personal relationships and moral duties tied to those relationships have a much higher value than abstract rights or impersonal laws. ${ }^{5}$

This so-called natural law could be translated into written laws. Social harmony and social order took precedence over individual rights. Under Confucian philosophy, conciliation and compromise were the ideal goals of justice in resolving a dispute. There was no adversarial struggle over technical rights based on legal principles. "The morally superior person guided by $l i$ ('correct' behavior protecting the social order, involving moral propriety through ritual) will be ready to adjust his conception of his rights to the needs and demands of others. He will avoid hostile confrontation and prove his moral superiority by being prepared to yield."6

China was a nation following a Confucian philosophy of natural law which elevated morality above the law and fused the two. ${ }^{7}$ China had a highly developed bureaucracy and system of administration. The Confucian rule of reason demanded that laws reflect custom and public opinion. From 1200 B.C. to 1911 A.D., Chinese legal codes adopted Confucian philosophy to varying degrees. Under legal codes enacted during the later Chinese dynasties, the function of law was no longer to sustain social harmony or to provide a framework for correct social interaction. These codes "created no rights of citizens, no general legal framework independent of the state and no body of civil law as distinguished from criminal law." 8 These codes instructed

3. Id. at 172 n.6. See Shao-Chuan Leng \& Hungdah Chiu, Criminal Justice in Post-Mao China 36 (1985).

4. Donahoe, supra note 2, at $171 \mathrm{n} .3$ (citing Baum, Modernization and Legal Reform in Post-Mao China: The Rebirth of Socialist Legality, 19 Stud. Comp. Communism 69 (1986)). See also R. UnGer, Law in Modern Society (1976).

5. Tay, The Struggle For Law in China, 21 U.B.C. L. Rev. 561 (1987).

6. $I d$.

7. Id.

8. Id. at 563 . 
government officials on how to maintain social harmony by punishing persons who breached that harmony. ${ }^{9}$

In 1911 the throne fell, and within one year China became a nationalist republic with a constitution containing an American-style Bill of Rights. ${ }^{10}$ With this constitution, which was redrafted several times between 1912 and 1931, China also adopted a civil law system composed of the Six Codes of the Guomindang modeled on European legal codes. The six codes were the Organic Law of the Courts, Commercial Law, Civil Code, Criminal Code, Civil Code of Procedure, and Criminal Code of Procedure." ${ }^{1}$ The codes and other laws governing commercial and business activities were drafted by foreign-law-trained Chinese with the help of Western legal scholars. They were used for the most part in cities to govern business transactions and relations with foreigners. ${ }^{12}$ The majority of Chinese in the countryside knew little of these legal codes and clung to Confucian teachings as their guide to the natural law. ${ }^{13}$

The adoption of these Western-style codes marked a significant turning point in Chinese legal history as China, for the first time, moved away from traditionalist Chinese society and Confucian philosophy. This new conceptual framework for China's legal system was modeled after European civil codes based on Roman law in which human activity was governed, ideally, by the decisions of individuals. The German Civil Code adopted in 1900 was the principal influence on the legal codes of Japan, China, and the Soviet Union. Many European codes were influenced by German legal analyses and definitions of such concepts as "persons," "juristic acts," and "obligations." The Chinese Criminal Code drew on portions of the criminal codes of Hungary, Germany, Holland, Italy, Egypt, Siam, and Japan. ${ }^{4}$ The Civil Code was based on the Swiss Code; and the Code of Civil Procedure was based on the Austrian Code. ${ }^{15}$ "The courts were organized on the French model, except that China followed the Anglo-American principle of separating the judiciary from the executive." 16 These new Chinese codes were taught in universities and had little application for the vast majority of Chinese. In reality, the new codes were academic or foreign law in China. ${ }^{17}$

The early Chinese Civil Code followed the German civil law tradition and adopted the concept of "juristic act." A juristic act is a free exercise of will constituting self-determination and is perhaps the most distinctive feature of the German Civil Code. Juristic acts include contracts, deeds, and wills. The

9. Id.

10. Id. at 564 .

11. Id.

12. Jones, Some Questions Regarding the Significance of the General Provisions of Civil Law of the People's Republic of China, 28 HARv. INT'L L.J. 309, 313 (1987).

13. Id.

14. Tay, supra note 5 , at 564 .

15. Id at 564-65.

16. Id. at 565

17. Jones, supra note 12 , at 313 . 
Chinese were also influenced by the Japanese methodology for adapting the German Civil Code to a natural law legal tradition. ${ }^{18}$

\section{III}

\section{The Soviet Influence}

When the Communists came to power in 1949, the Chinese Government repealed the six codes and abolished the existing legal and judicial systems. ${ }^{19}$ The private practice of law was banned." "Having done away with the Nationalist legal institutions, the new government began experimenting with the establishment of formal, Soviet-style judicial organs, such as people's courts and people's procuracies." 21 Regional authorities issued directives and regulations governing policy, governmental organization, public security, and criminal law. ${ }^{22}$

This was a period of revolutionary euphoria manifested by swift policy changes and the implementation of communist political philosophy. Law was politicized and used as a tool for working class rule. Between 1949 to 1953 , 148 laws and regulations, governing a wide range of political, economic, and social activities, were enacted; but no new codes were established. ${ }^{23}$

Because of the insufficient number of trained Communist judicial personnel, many judges, procurators, court clerks, and prison administrators who had served under the Nationalists were initially allowed to continue to hold office. However, in 1952 a nationwide Legal Reform Campaign was launched, resulting in the removal from office or condemnation as counterrevolutionaries of these experienced judicial officials. ${ }^{24}$

In 1952 and 1953, the Judicial Reform Movement attacked Western legal concepts still prevalent in China. ${ }^{25}$ "Legal concepts such as the separation of law from politics, the equality of all persons before the law, the independence of the judiciary, statutes of limitation, ... . were held up as aiding landlords and counter revolutionaries at the expense of the people."26 Soviet legal scholars came to China to teach and Chinese students traveled to the Soviet

18. Id. at $310 \mathrm{n} .7$; see also Y. Noda, Introduction to Japanese LaW 48.52 (A. Angelo trans. 1976).

19. Hsia \& Zeldin, supra note 1 , at 251 .

In February of 1949, the Chinese Communist Party swept away the legal organs and the entire body of laws of the Nationalist regime when it issued the "Directive Regarding the Abolition of the Guomindang's Complete Book of Six Codes and the Affrrmation of the Legal Principles in the Liberated Areas." In September 1949, this Party directive was incorporated into the Common Program of the Chinese People's Consultative Conference, which was the temporary basic law of the state until 1954. Article 17 of the Common Program states: "All laws, decrees, and judicial systems of the Guomindang Reactionary Government which oppress the people shall be abolished. Laws and decrees protecting the people shall be enacted and the people's judicial system shall be set up."

20. See Cohen, China's New Lawyer's Law, 66 A.B.A. J. 1533 (1980).

21. Hsia \& Zeldin, supra note 1 , at 251.

22. See Tay, supra note 5 , at 568-69.

23. Hsia \& Zeldin, supra note 1, at 251-52.

24. Id. at 252.

25. Id.

26. Id. at 569 . 
Union to study law. ${ }^{27}$ Under the influence of Soviet legal concepts and models, "more than 800 collectives called 'Legal Advisory Offices,' whose activities were coordinated by 19 lawyers' associations" under the supervision of the Ministry of Justice, were established in the major cities by the mid1950's. ${ }^{28}$ They were staffed by 2500 full-time and 300 part-time "people's lawyers."'29

From 1954 to 1957 , significant progress was made toward the creation of a formal legal system. Chinese scholars and government officials relied heavily on Soviet legal models in this effort. A constitution, codes of laws, and judiciary were being established.

The period from 1954 to mid-1957 has been referred to as the golden age of legal development in the PRC because of the considerable progress made in the creation of a formal legal system. The framework for the system was established with the promulgation in 1954 of the first PRC Constitution. It was then supplemented by organic laws for the courts and the procuracy. In addition, during this period scholarly research flourished and several law books and two major law journals, Zhengfa yanjiu (Political-Legal Research) and Faxue (Jurisprudence), appeared. Serious work on the drafting of a criminal code and a civil code also began. ${ }^{30}$

Soviet legal codes and principles were readily accepted as models for the Chinese legal codification until 1957 when a most dramatic shift in Chinese politics took place. The Soviet-Chinese alliance shattered.

" [T]he 1957 break between China and the Soviet Union swept most of the ground from under the feet of those who advocated more regularized legal provisions and procedures."'31 Led by Mao Zedong, Chinese leaders abandoned the Soviet legal model and attacked all legal institutions and the persons who supported them. "The purges of judicial codes in 1952 were held up as a model for the relationship between law and politics and as correctly emphasizing the class character of law."32

Between 1957 and 1965, some Chinese jurists, legal scholars, and legal authorities urged modernization of the legal system. Several attempts were made to draft uniquely Chinese legal codes without using any models, but none was successful. ${ }^{33}$ They sought to establish such Western legal concepts as judicial independence, equal justice before the law, and due process of law. ${ }^{34}$ Their reform movement came to a sudden halt in 1959 when these reformers were condemned as rightist intellectuals with antisocialist views attempting to use law against the Party and to negate the class nature of law. ${ }^{35}$ The Ministry of Justice disbanded, law schools closed, legal research halted, and the legal profession disappeared. ${ }^{36}$ Legal principles set forth in the 1954

\footnotetext{
27. See Gray, China's Changing Legal Climate, 31 L. Quad. Notes 1, 2 (1987).

28. See Cohen, supra note 20; Hsia \& Zeldin, supra note 1, at 270.

29. Hsia \& Zeldin, supra note 1 , at 270.

30. Id. at 252.

31. Tay, supra note 5 , at 571 .

32. Id.

33. See Tay, supra note 5. See also Jones, supra note 12; Hsia \& Zeldin, supra note 1, at 253.

34. Hsia \& Zeldin, supra note 1 , at 252.

35. Id. at 253. See Tay, supra note 5 , at 569.

36. Id.
} 
Constitution such as equal justice before the law and judicial independence were condemned by the Party as rightist ideology. ${ }^{37}$

Chairman Mao's Cultural Revolution began in 1966 and destroyed any possibility of China ever adopting a totally Soviet-style legal system based on communist legal principles. Revolutionary morality dominated political idealogy, and the party, a mass organization of the people, ruled the state. During the period from 1966 to 1976, almost no laws were enacted and no law books or journals were published. ${ }^{38}$ "Law, bureaucracies and distinctions of knowledge and education would have no role."39 Western, including Japanese, and Soviet legal models were attacked. Chinese legal scholars and former members of the Chinese legal profession sought new non-legal careers; some were beaten, humiliated, imprisoned, and reeducated in labor camps. ${ }^{40}$

\section{IV}

\section{The New Chinese Civil Law Tradition}

From 1949 through 1976, there were no general Chinese codes of law in effect. With the death of Mao and the fall of the Gang of Four in 1976, a new China began to emerge. This new China emphasized "social legality" and the protection of individual rights, restored "people's lawyers" as part of the judicial system, and revived the Ministry of Justice. ${ }^{41}$ The legal and judicial systems were reestablished and formal legal education was given new prominence in higher education. ${ }^{42}$ Law became an important part of the movement to encourage international trade, foreign investment in China, and international economic cooperation. ${ }^{43}$ However, the influence of a thirty-year communist rule continued. The structure and role of the ruling political party and its social control continued. General socialist political theories and collective economic principles remained strong. ${ }^{44}$

37. Id. The 1954 Constitution was neither repealed nor acknowledged.

38. Hsia \& Zeldin, supra note 1, at 254.

39. Tay, supra note 5 , at 571 .

"Lawlessness was openly praised, and the Gang of Four encouraged Red Guards to smash the police organs, procuracies and courts." Hsia \& Zeldin, supra note 1, at 254 (citing In Praise of Lawlessness, Renmin ribao (People's Daily), Jan. 31, 1967, at 6, and Deal a Head-on Heary Blow to the Habitual Influence of the Old Public Security Organs, Procuracy and Courts: Thoroughty Eradicate the Root of the Black Revisionist Line of Liu, Deng, Peng, and Lo, 3 Qui peng lo zhanbao (Yanking out Peng and Lo Battle News) 2 (Feb. 1968)). "This Red Guard publication is in 3 Red Guard Publications 0638 (1975), a compilation assembled by the Center for Chinese Research Materials of the Association of Research Libraries." Id. at n.29.

40. Hsia \& Zeldin, supra note 1, at 253. See also Tay, supra note 5; Cohen, supra note 20; Jones, supra note 12.

41. Cohen, supra note 20, at 1533. The Soviet model of legal advisers' offices has been established in major cities and emphasis is being placed on the importance of litigants having legal representation. Hsia \& Zeldin, supra note 1, at 270.

42. See generally Hungdah Chiu, Chinese Views on the Sources of International Law, 28 HARv. INT'L L.J. 289 (1987).

43. Id.

44. Tay, supra note 5 , at 572 . 
Certain basic trends remain: The primacy of the party and the dictatorship of the proletariat; the correctness of Marxism-Leninism-Mao Thought (before 1958); and the centrality and overwhelming importance of the state and collective economy based on public ownership of the means of production. So does the general rejection of capitalism as a system of exploitation. 45

On November 29, 1979, the Standing Committee of the National People's Congress adopted a resolution declaring that all laws enacted during the 1950 's and 1960's were to remain in effect if they did not conflict with the Constitution or more recently enacted legislation. ${ }^{46}$ Similarly, the Chinese Government reviewed more than 50,000 regulations enacted since 1949 and abolished or reversed those found to conflict with the Constitution and newly promulgated laws or regulations. ${ }^{47}$ These actions constituted an awkward but systematic merging of statutes and regulations which were inspired by the Soviet model, German model, or other civil law and/or socialist legal traditions.

The Chinese Government recognized that to obtain the goals of modernization it needed to create a secure and orderly environment for economic development. ${ }^{48}$ Success in achieving economic modernization was linked politically with the "construction of a 'socialist legal system' in which strictly observed laws would guarantee the stability of a new democratic system." 49 Party leadership believed that a strong legal system encouraged economic development by creating a secure legal environment for foreign investment, importation of foreign technology, and promotion of industrial exports. ${ }^{50}$ Given this new priority placed on strengthening the Chinese legal system and its higher status in the Chinese political arena, the legal profession must attract talented people trained in foreign trade practices and negotiation, the necessary skills for economic modernization.

Pre-Cultural Revolution legally trained Chinese have been moved back into employment positions which utilize their legal skills. They are a mixture of persons trained in Western and Soviet legal traditions. In developing a new legal system with Chinese characteristics, Chinese government officials

45. Id. at 575 .

46. Hsia \& Zeldin, supra note 1 , at 259

47. Id. at 260 .

48. The program of Four Modernizations-agriculture, science and technology, industry, and national defense-was introduced in the Fourth National People's Congress in 1975. Hsia \& Zeldin, supra note 1 , at 254 n.33.

49. Id. at 254-55. The Economic Law Research Center was established by the State Council "to supervise the national economic legislation program and organize the drafting of economic laws and regulations." Id. at 261. In 1981, this Center issued a detailed set of guidelines stressing that priority should be given to drafting economic legislation and that new legislation should take account of domestic and foreign practical experience. Id. at 261 n.66. See Several Proposals on Strengthening Law-Making Work of the Economic Legislation Research Center of the State Council, 19 Zhonghua Renmin gongheguo guowuyuan gongbao (Bulletin of the State Council) 593 (Oct. 25, 1981). Id. at n.63. The guidelines stated "that economic legislation should be centrally planned and coordinated under the guidance of the State Council through the coordinated efforts of legal offices attached to the ministries and commissions, and through the Economic Law Research Center." Id. The guidelines also suggested that implementation of economic guidelines be closely supervised by the courts, but emphasis should be placed on mediation and arbitration in dispute resolution.

50. Id. at 256. 
and legal experts are willing to borrow concepts from all foreign legal systems. Underneath newly adopted foreign legal concepts remains a traditional Confucian philosophy that too strong a reliance on positive law is evidence of a breakdown in the social order and a lack of harmony between the state and society.

Ultimate decisionmaking authority is still in the central government. Many functions performed by civil law in Western society are performed by administrative agencies making up the Chinese government bureaucracy. ${ }^{51}$ Analogous to the practice of administrative guidance employed by Japanese ministries to influence private actions without the sanction of law is the practice of the Chinese central government to control private activities by inducing "the persons concerned to decide correctly, that is, in accordance with government policy" without resorting to legal sanctions or government orders. ${ }^{52}$

Most Chinese persons engage in a large variety of economic and social activities and resolve disputes involved in those activities without coming in contact with the formal legal system. ${ }^{53}$ As in Japan, litigation in a court of law is not considered a normal way to resolve a dispute. Custom and extrajudicial dispute settling mechanisms are utilized not only by private parties but by public entities. ${ }^{54}$ Decisions declaring someone right and someone wrong are

51. Jones, supra note 12 , at 316 .

52. Id. at 317. Administrative guidance (gyosei shido) is an extralegal source of governmental power for the implementation of government regulation and supervision. It must be distinguished from the executive, legislative, and administrative powers in the United States. Professor Dan F. Henderson has described "administrative guidance" as "power derived again from traditional concepts of inherent power of the administration, largely a carry-over from imperial theories, so that administrative guidance is more the mode of expressing these powers than their source. . . By its very nature, guidance is not legally defined, nor are there rules or court precedents on such a subject." D. Henderson, Foreign Enterprise in Japan 200-01 (1973).

Administrative guidance refers to actions by governmental agencies that result in voluntary compliance with government policies or objectives. Actions may take the form of instructions (Shii), requests (Yobo), warnings (Keikoku), suggestions (Kankoku), and encouragements (Kansho). The government agency's suggestions or recommendations are not enforceable in a court, and no legal sanctions against a non-complying party are available. All forms of administrative guidance have no legal binding power or coercive authority.

In Japan, failure to comply with administrative guidance does not result in official punishment or judicial order to perform. Failure to comply does result, however, in a loss of face by the governmental agencies, which subsequently may become extremely uncooperative in providing future services, advice, regulatory exceptions, licenses, and permits to the non-complying party. See Narita, Administrative Guidance, 2 LAW IN JAPAN 45 (Anderson trans. 1968). Government agencies also may publicize non-compliance as a sanction or use the threat of such actions to encourage compliance. Complying parties may be rewarded through government subsidies.

In China, it seems more likely that the Chinese Government resorts to legal sanction or government order to ensure compliance by private parties if voluntary compliance is not forthcoming. However, this might not be the case if Chinese government officials anticipated bad publicity from a legal sanction or government order. Then, the Chinese government agencies might retaliate in the same manner as Japanese government agencies to punish private parties for noncompliance with government recommendations or suggestions. It is this author's belief that most Chinese will comply with government inducements because such compliance with government authority is a carry-over from Confucianism.

53. Jones, supra note 12 , at 318 .

54. Id. at 319. 
not a desirable goal. Settlements and compromises are preferable. Even in court, Chinese litigants generally do not obtain a clear defeat or victory. ${ }^{55}$

The Chinese courts are apparently quite capable of recognizing the validity or invalidity of a claim and granting a request for relief or denying it. But they are more likely to try to work out a settlement that will really end the dispute in the minds of the parties and that will cause the one who has done wrong to understand his errors. The Chinese courts are also very conscious of the possible implications for society of particular behavior and of the way it is handled by the courts. In other words, the work of the court is an aspect of the work of government in achieving its purposes. It is not just settling a private dispute. ${ }^{56}$

Professor William C. Jones interprets this pattern of judicial decisionmaking by Chinese courts to be attempts to further government policies. ${ }^{57}$ This may be true to a certain extent but it may also reflect an underlying Confucian tradition that conciliation and compromise are the ultimate goals in resolving a dispute.

China's new period of legal development emphasizes socialist legal construction. A new state Constitution was adopted in 1982, and the following new laws were enacted: the Inheritance Law, Mineral Resource Law, Foreign Economic Contract Law, Election Law, Joint Venture Law, Bankruptcy Law, Trademark Law, and Patent Law. ${ }^{58}$ The new Constitution stresses the importance of law, and priority is given to drafting laws to facilitate international commerce. To a certain extent, this is somewhat reminiscent of the Meiji era in Japan when the Japanese drafted a constitution and legal codes which facilitated their commercial and social interactions with the Western world. So too, China, in its effort to accelerate economic development through trade with the Western world, had a need to define its legal system in terms which could be understood by and which would facilitate commercial activities with foreign nations and companies. China wanted to attract foreign investment and technology and needed a legal system with familiar legal concepts to guarantee the protection of a foreign enterprise's investment in China or license of technology to a Chinese enterprise.

55. Id. at 322 .

56. Id. at 323 .

Chinese courts are handling more civil cases each year and some Western legal scholars argue that this means that a formal legal system is coming to be established and accepted. Hsia \& Zeldin, supra note 1 , at 265 . However, approximately 80 percent of these cases are settled by mediation rather than adjudication. Id. (citing Zheng Tianxiang Work Report of the Supreme People's CourT, translated in FBIS, DAILY REPORT, Apr. 23, 1983, at K7). Lawsuits involving economic law have doubled and redoubled since 1983. Id. "From 1979 to mid-1986, the people's courts processed over half a million cases involving economic law. . ." Id. at 266.

57. Id.

58. Between 1979 and 1987, 57 new laws, 29 of which govern economic affairs, were established and a new constitution was adopted by the National People's Congress. Hsia \& Zeldin, supra note 1 , at 250 . 


\section{The General PRINCIPLES OF CIVIL LAW}

On January 1, 1987, China adopted its new civil code, the General Principles of Civil Law of the People's Republic of China. ${ }^{59}$ This code followed the enactment of the Economic Contract Law in 1981. Economic law is viewed as an integral part of China's modernization and is treated as a separate body of law. Many economic law topics receive only summary treatment in the General Principles. China has established a regulatory system of economic law under the General Principles similar to the regulatory structure in post-war Hungary and Poland. ${ }^{60}$ The legal codes in these countries recognize the independent rights, duties, and responsibilities of the state enterprise in its civil activities ${ }^{61}$ In China, civil law regulates horizontal economic relations between subjects; and economic (administrative) law, as administered by the state, regulates vertical economic relations and civil activities. China's new legal system, embodied in the General Principles and special economic statutes, contains an extensive interaction between socialist and free enterprise principles (commodities exchange economy).

The General Principles contains 156 articles in nine chapters. Articles govern property rights, personal rights, intellectual property rights, marital rights, civil rights, legal responsibilities, tort liability, and legal remedies. State, collective, and individual property rights are protected by law. Contractual rights to land, natural resources, scientific discoveries, and state property are also protected. ${ }^{62}$ With respect to civil rights, all persons exercise "their rights in conformity with the law and morality and do not harm social welfare."63 The General Principles attempts to integrate laws governing economic activities. ${ }^{64}$

In Western civil law systems, the legal person is an important concept as an economic organizational form. First established in German civil law, this legal person assumes a somewhat new identity under the General Principles. Unlike the German counterpart, the Chinese concept of an enterprise legal person does not distinguish between the public and private legal person. ${ }^{65}$ The enterprise legal person is not clearly defined. The General Principles applies to all relevant activities and transactions between private individuals, collective public enterprises, government agencies, and private companies.

59. Prior to the promulgation of the General Principles, knowledgeable Chinese (People's Republic of China and Taiwan) looked to general Chinese and non-Chinese civil law treatises to study legal problem analyses. Jones, supra note 12 , at 324-25. "There seems to be no question that civil law was thought to exist in China. It was apparently also a sort of Gemeinrecht or common law that consisted of the general ideas current in civil law circles throughout the world, though organized in the German way." Id. at 325.

60. Tong Rou, The General Principles of Civil Law of the PRC: Its Birth, Characteristics, and Role, LAw \& Contemp. Probs., Spring 1989, at Part III.B.

61. Id. at MS 16-17.

62. Hsia \& Zeldin, supra note 1 , at 263.

63. Id. at 264

64. Id. at 265 .

65. Id. at 575 . 
Borrowing from other civil law systems, the General Principles establishes the concept of ownership in the enterprise legal person. Bankruptcy can terminate the Chinese public/private enterprise legal person. A wholly foreign-owned enterprise is clearly an independent private enterprise legal person capable of making its own decisions. ${ }^{66}$

Theoretically, the domestic enterprise legal person, public or private, can exercise legal rights, own property, negotiate business ventures, and make its own decisions. This model for society permits private legal enterprise persons to make their own decisions. There is control, potential and actual, by the government, but most of the activity in society is controlled by independent decisionmakers, some of which are collectivities-juristic persons. This is the model of modern civil law systems in France and Germany ${ }^{67}$ and differs significantly from the Maoist Communist model of government control and a centralized economy. However, this may be more theory than reality because large-scale economic enterprises acting independently and representing private ownership of capital create serious ideological problems and cannot be tolerated in a socialist society.

The General Principles is written in very broad terms which cannot be used directly to resolve legal problems. In Germany, the General Principles would be called a "General Part" which would be supplemented with statutes, sometimes called "Special Parts," which address specific situations. ${ }^{8}$ The General Principles defines general legal concepts in such areas as torts, property, and obligations law, but must be read in light of special statutes like the Economic Contract Law in addressing specific areas of regulation. Consequently, the General Principles, like the German Civil Code, contains general principles of "honesty and good faith" applicable to all legal transactions in China. ${ }^{69}$ The Economic Contract Law contains the rules for specific contract types such as sales, hire, construction, insurance, loans, and so on.

The General Principles therefore theoretically constitutes the basic principles governing Chinese society in much the same way as the European legal codes set forth general principles of law. The General Principles makes no reference to political ideology and is fairly indistinguishable from European civil codes. ${ }^{70}$ On the other hand, the Economic Contract Law refers to guidance by government authorities and implies that legal enterprise persons can only

66. The Law of the People's Republic of China for Enterprises with Sole Foreign Investment (1986). A translation can be found in CCH-China I 13.506, $\$ 11.2$.

67. Jones, supra note 12 , at 328 .

68. See J. Merriman \& S. Clark, Comparative Law (1978); see also H. Lawson, A Common LaWyer Looks at the Civil LaW 164-69 (1953).

69. General Principles of Civil Law of the People's Republic of China, art. 4.

70. Professor William C. Jones believes that there is a strong possibility that the General Principles is a political statement whose "aim was to confirm, in as permanent a form as possible, the new economic organization of the country, including the individual responsibility system in the countryside and the decentralization of decision-making power in industry." Jones, supra note 12, at 325. These provisions are an affirmation that individual economic and commercial activities are recognized by law and entitled to legal protection. Id. at 326. 
enter obligation relationships permitted by the state and are not permitted to have freedom of choice in their business relationships.

The General Principles provides general workable rules for partnerships and family businesses without reference to any socialist or free enterprise theoretical underpinnings for these institutions. ${ }^{71}$ Principles of agency, contracts, and conflict of laws have their roots in Western legal traditions and may reflect the influence of older Chinese scholars educated before 1949 in Nationalist China and recent studies by Chinese legal scholars of Western legal systems during the last fifteen years. ${ }^{72}$ The General Principles is obviously drafted by persons with a direct knowledge of French and German civil codes, which are also systematic codes building on the abstract concept of "legal act." ${ }^{\prime 3}$ However, China has no intention of departing too far from a socialist orientation. Primary importance is still given to the centrality of the state and maintenance of a collective economy based on public ownership of the means of production. ${ }^{74}$ Capitalism is still rejected as an economic system of exploitation.

Professor Gray noted in his remarks delivered at the Conference the significant input in the new civil code drafting process by Chinese legal scholars trained in the Soviet Union or by Soviet teachers in China during the 1950's; but he was quick to point out that the new Chinese General Principles is not a borrowed code in the same way that the Soviets borrowed from the German Civil Code. There are no translations of whole sections of the German or Soviet Civil Codes.

The German-style Soviet Code's influence is readily apparent in the General Principles' "socialist" provisions. ${ }^{75}$ Professor Gray mentioned several examples. In China, like the Soviet Union, state enterprises receive property from the state (land, buildings, raw materials, and money) and sell products produced in the same way as a private enterprise sells products. To avoid the concept of state enterprise "ownership" of this property, the Soviet Fundamental Principles defined the relationship between the state enterprise and the property as the right of the state enterprise to operate and manage property. The state enterprise right to operate and manage property amounted to ownership but was not described as such. The Chinese adopted this distinction in the General Principles. ${ }^{76}$ Another example is the concept of strict liability or liability without fault. In the General Principles, Chinese Civil Code section 132 on liability without fault is close to a paraphrase of Soviet Civil Code section 454.

71. Gray, supra note 27 , at 2 .

72. Id.

73. Id.

74. Tay, supra note $\mathbf{5}$, at $\mathbf{5 7 5}$.

75. Despite being modelled on the German Civil Code, the Soviet Code permitted the development of a highly centralized economy and limited individual initiative. Jones, supra note 12 , at $328-29$.

76. See Gray, supra note 27. 
However, Professor Gray also stated that the American contract law policy of commercial flexibility as expressed in articles 34 and 38 on Chinese economic contract law drives a Soviet legal scholar "up a wall." The Soviet Civil Code has many fixed or absolute positions which are not being adopted by the Chinese. China, as a society in transition, is reluctant to adopt legal principles or rules which limit flexibility in commercial transactions. According to Professor Gray, the General Principles is a unique Chinese product with Soviet-style elements. Different aspects of civil and common law legal traditions have been adopted, adapted, and rejected as models for the emerging Chinese legal system.

Equally importantly, Chinese law reflects the continued influence of Marxist-Leninist-Maoist (before 1958) thought on government administration, the role of law, economic regulation, educational policies, cultural programs, and foreign policy. This socialist agenda is amply set forth in the 1982 State Constitution and the Criminal Law and Criminal Procedure Law of the People's Republic of China. ${ }^{77}$ The Criminal Law and Criminal Procedure Laws are organized along patterns set forth in Soviet and Continental civil law systems but in substance are law codes of an "authoritarian socialist society" that view "most forms of harm caused to other citizens or the state as matters for criminal control by the state rather than civil action by the individual harmed."78 Although both laws indicate that court proceedings are to be in accordance with law and not subject to political interference, Confucian philosophy, so deeply imbedded in Chinese culture, continues to influence actual legal analysis and practice because "law and morality are still closely intertwined in all Chinese legal proceedings, especially criminal."79

Chinese legal scholars and government officials accept the necessity for a legal system easily understood by Western societies. The study of civil law has been an academic pursuit for many years. China has had legal codes in some form for hundreds of years. In drafting the new civil code, Chinese legal scholars and lawyers utilize Soviet, German, and Continental models which have previously been used to draft earlier Chinese codes and are studied in universities. Few persons, especially Chinese government officials, have much experience in applying civil law to social and commercial activities in Chinese society. ${ }^{80}$ Practical application of the General Principles through the interpretation of specific statutes is limited by several factors. First, there are simply too few judges and lawyers with adequate legal training. Even if the average Chinese somehow

became accustomed to using the legal process to get disputes settled, or to going to lawyers for advice, if he wished to sue or get documents drafted, it would be

77. Tay, supra note $\mathbf{5}$, at $\mathbf{5 7 8}$.

78. Id.

79. Id

80. Jones, supra note 12 , at 330 . 
impossible for him to do so. The number of legally trained persons is simply too small in comparison to the whole population, and it will remain very small. ${ }^{81}$

Second, few government officials understand the significance of adopting a German-style civil code recognizing self-determination in private parties through application of the "juristic act" concept. For these persons, so long as it makes no offensive pronouncements, has no negative applications towards government, and satisfies Western investors, its status will be maintained. ${ }^{82}$

Despite the various legal reforms and the government's emphasis on legal education, many Western scholars wonder whether or not Chinese leaders fully understand and accept the basic legal concepts which have been adopted in the General Principles. ${ }^{83}$ Of particular concern to Western scholars is the notion of judicial independence. During a recent anti-crime drive, the courts, procuracy, and police worked together very closely to increase the speed and accuracy with which matters are handled. ${ }^{84}$ According to Liu Fuzhi, former Minister of Public Security, "being overly concerned with the problem of judicial independence only serves to 'bind one's hands and feet' and stems from the influence of eastern bourgeois judicial thinking." 85 Close cooperation between the judiciary, police, and prosecutors threatens the development of judicial independence and, more importantly, brings into question the relationship between law and Party policy in China. ${ }^{86}$ Although many Chinese leaders suggest that law should take precedence over Party policy, they maintain that law is merely a formalized version of a mature Party policy. ${ }^{87}$ Consequently, it is unclear where Party policy ends and formalized law begins. Do changes in Party policy supersede or reinterpret prior legal formulations of mature Party policy? "In practice, laws have in some cases been disregarded when they have come into conflict with policies." 88

81. Id. (citing Leing, The Emergence of the Legal Profession in the People's Republic of China, 6 N.Y.L. Ch. J. INT'L \& Comparative L. 275 (1985)). According to a 1986 estimate, there are 13,000 full time lawyers in China and the number is expected to increase to only 50,000 by 1990 . Hsia \& Zeldin, supra note 1 , at 270 .

82. See generally Jones, supra note 12.

83. Hsia \& Zeldin supra note 1 , at 281 .

84. Id. at 283 .

85. Id.

86. Id.

87. Id. at 282 .

Under the new Constitution, "the state upholds the uniformity and dignity of the socialist legal system. . . No organization or individual may enjoy the privilege of being above the constitution and the law." Hsia \& Zeldin, supra note 1, at 250 (discussing art. 5 of the Chinese Constitution (Xianfa) and BEIJING REv. 12-13 (Dec. 7, 1982)). "No organization" also includes the Party, which must conduct its activities within the written constraints defined by the Constitution and the law. Id. (citing BeIJING Rev. 10 (Sept. 20, 1982)).

88. Id. There are also examples of this practice in Japan, where laws adverse to current government ministry policies or objectives are simply not enforced 
Western law is being taught in Chinese universities. ${ }^{89}$ Chinese students are again traveling abroad and studying Western law and its applications throughout the world. As this new generation of legally trained persons assumes roles of leadership and authority throughout China, including teaching positions in primary and secondary schools (because the study of law is an undergraduate discipline in civil law countries), there could be a growing acceptance of Western-style law and its application to Chinese society. ${ }^{90}$ If that is true, enterprise legal persons could become more independent and formal. Contracts could assume a more important role in domestic commerce in the future. ${ }^{91}$ The Japanese model of Western-style law adoption may provide insights on the future course of law in China, because the more probable outcome is the emergence of some hybrid legal system through future application of Western-style law in China. This new legal system will no doubt be distinctly Chinese in character with only some aspects of Western-style legal form and flavor.

89. Formal legal training is now provided by various institutes under the supervision of the Ministry of Justice and university departments of law. Most university law students are the equivalent of U.S. high school graduates.

Standard law courses are Constitutional Law, Criminal Law, Criminal Procedure, Civil Law, Civil Procedure, Administrative Law, Economic Law, International Economic Law, and Labor Law. Hsia \& Zeldin, supra note 1, at 273. The university law schools also offer graduate legal studies, at the masters' and doctorate levels. Chinese law school graduates are now studying in United States and European law schools. "In addition, the Ministry of Justice has established junior-college and highschool level paralegal programs, and correspondence, television, and evening law schools." Id. at 274. It will be interesting to see if the recently implemented (September 1986) uniform examination system for new lawyers is used to ensure competence in the legal profession as in the United States or is used to limit entry into the legal profession as in Japan. For a more thorough discussion of law training in the PRC, see Gao, Today's Legal Thinking and its Economic Impact in China, LAW \& CONTEMP. ProBs., Spring 1989, at -

90. The commitment to disseminating legal knowledge has extended beyond the narrow legal community. In 1979, the government launched a mass legal education campaign to familiarize the people with the content of the seven major laws adopted in July of that year. The campaign used television and radio broadcasts, newspaper articles, and group meetings.

The commitment to publicizing laws was given new impetus, at a national conference on law propagation and education, held in June 1985 by the Communist Party Central Committee's Propaganda Department and the Ministry of Justice. Participants formulated a "Five-year Plan for Spreading Basic Legal Knowledge Among All Citizens." In his speech to the conference, Minister of Justice Zou Yu said that "stress should first be laid on cadres, especially leading cadres, ... . [and] on young people." Chen Pixian, member of the Secretariat of the Central Committee and Secretary of the Central Committee's Political-Legal Committee, remarked that students at all levels, from primary school through the university, should study the legal system, and that the mass media should be utilized to educate the public about the legal system.

Apparently, more than 200,000 people have been trained to explain the laws, and textbooks and popular readers have been prepared to help workers, peasants, and soldiers. The popularization drive is being conducted by propaganda and judicial departments of Party committees, at various levels in conjunction with government organizations. Localities are officially permitted to develop their own goals, methods, and teaching materials in accordance with the national plan.

Hsia \& Zeldin supra note 1, at 277-78.

91. See also Jones, supra note 12, at 331 . 
Little information exists on how the General Principles and Economic Contract Law are being applied to transactions between domestic legal enterprises and transactions between a domestic legal enterprise and a foreign legal enterprise. Do legal enterprise persons utilize lawyers and refer to existing law in establishing their relationships to the same extent in domestic transactions as they do in international transactions?92 If the answer is "no," and I think it is, the Chinese legal system is bifurcated and shows a different legal face to foreign enterprises. In a sense, this is also similar to the Japanese legal system in which contractual relationships between Japanese companies are much more informal and very general as compared to contractual relationships between Japanese companies and foreign companies. Japanese companies do not tend to consult lawyers in the negotiation and preparation of domestic contracts. Similarly, it is doubtful that Chinese enterprises consult the law or lawyers in negotiating with each other. Like the Japanese Government, the Chinese Government probably plays a very active role in major contract negotiations involving Chinese enterprises with each other and with foreign enterprises. Directions and guidance are provided by the government bureaucracy. As in Japan, disputes between domestic enterprises are resolved through negotiation or mediation rather than in the courtroom..$^{93}$ This dispute settlement preference is a legacy of the Confucian legal tradition.

In the history of the development of its present legal system, Japan in many ways experienced the changes currently underway in the PRC. Some of the similarities are superficial; in Japan during the last years of the nineteenth century, the tension between advocates of a capitalist society and advocates of an absolutist state was marked. Still, in format as well as in the pervasiveness of the cultural traditions discussed earlier in this article, the modern laws of Japan and the PRC seem to overlap. Japan is also a civil law country in which most legal subjects are covered by codes or statutes. The Japanese definition of a code (Hoten) is an enacted law which covers the basic law in a specific legal

92. "Increased contact with foreign lawyers and businessmen has expanded the scope of the lawyer's role in China." Hsia \& Zeldin, supra note 1, at 271. Legal advisers to state enterprises often work on matters involving foreign parties. More than 200 legal advisory offices specialize in foreign legal matters and provide legal advice to Chinese and foreign enterprises engaged in international trade activities. Id. However, the new Provisional Regulations governing lawyers, effective January 1, 1982, make very clear an important distinction between an American lawyer and a Chinese socialist lawyer. Id. at 281 . Unlike the American lawyer whose primary responsibility is to his client, the Chinese lawyer is a legal worker for the state whose foremost responsibility is to protect the correct implementation of state law. Id. For the Chinese lawyer, client interests and objectives are a secondary responsibility if there is a conflict with a state interest or objective.

93. Despite the movement to modernize and to establish a formal legal system, mediation remains the primary method of dispute resolution. Traditionally, civil disputes were resolved through elders acting as mediators. This is entirely in accordance with Confucian philosophy in which conciliation and compromise were the added goals of justice in resolving a dispute. In keeping with this Confucian tradition, "[t]he General Principles provide that the village or urban neighborhood mediation committees are responsible for mediating civil disputes and minor criminal cases." Hsia \& Zeldin, supra note 1 , at 280 . However, mediation is voluntary and the parties may file a court action if a settlement cannot be reached. Id. "It is estimated that the number of mediation committees has grown to almost one million and that, in 1985 alone, they settled more than six million cases." Id. at n.169 (citing People's Daily (overseas ed.), May 30, 1986, at 4). 
subject area in a systematic way. ${ }^{94}$ The major Japanese enactments are the Civil (Mimpo), Commercial (Shoho), Civil Procedure (Minju Sosho Ho), and Penal (Keiho), Criminal Procedure (Keiji Sosho Ho) Codes, and the Bills and Notes (Tegata Ho), Checks (Kogitte Ho), and Administration Litigation Acts (Gyosei Jiken Sosho Ho). ${ }^{95}$ The court's role is to interpret the statutory and code provisions.

Major legal codification in Japan took place in the late 1880's and 1890's. Prior to that time, Japan underwent several transitions. During the third and fourth centuries, social life and hierarchy were under a strong religious (Shinto) influence. Confucianism was added to this Shinto religious tradition in the fifth century and provided a strict hierarchical social order serving political purposes. Buddhism arrived in the sixth century and its doctrines also served existing political purposes. Law could not be distinguished from social rules and there was no foreign influence. Power was concentrated in the government of the emperor and powerful clans. "There was a highly centralized government in China, and in order to defend itself against possible invasion the national cohesion of Japan became a matter of great importance."96 By the beginning of the seventh century, "Japan had a state organization of a centralized type along the lines of the Chinese model. . . . The emperor governed personally, following the model of the despotic Chinese emperor, and all the Chinese political institutions were transplanted to Japanese soil."97

In the seventh century, the Japanese government promulgated several legal codes which were modeled on Chinese legal codes and incorporated Confucian doctrine and values. The language used in these Japanese codes was Chinese. These codes focused on administrative law, criminal law, and Confucian ideals governing social life.

Power was concentrated in the imperial government and Japanese law was non-judicial and non-procedural as it emphasized administrative practice for governing society. By the ninth century, there was a weakening in the central government with a corresponding rise in the power of a military class-clan society structure. By the twelfth century, the military class gained political control of the imperial government and the emperor reigned in name only. This military government established a feudalistic society dominated by clans.

This period of feudalism in Japan was dominated by the bushi (samurai). The moral rules of conduct governing the bushi were found in the bushido (code of chivalry). Although basically a customary system of rules, there was some written law associated with bushido. ${ }^{98}$ The system of morality founded by bushido is grounded in Confucianism and Buddhism. The older legal codes

94. H. Tanaka, The Japanese legal System 60 (1976).

95. Id.

96. Y. NoDA, supra note 18.

97. Id.

98. Id. at 30 . 
based on Chinese law were never formally abrogated, but with the growth of feudalism, their influence declined outside the domain of the imperial court. ${ }^{99}$

Feudalism reached its peak during the Tokugawa period of Japanese history and lasted from roughly 1603 until 1868. Japan isolated itself from the rest of the world, particularly the Western world. Confucianism was adopted as the official ideology and provided the moral ideals on which the hierarchical social relationships of Japanese feudalism were founded.100 Customary law supported the existing social order and legislation dealt with matters concerning the support of the feudal regimes. This legislation normally took the form of directives to feudal lords (daimyos) or existing judicial authorities. Japanese laws, for the most part, were a means of constraint or enforcement used by government authorities to achieve government purposes and to maintain a strict code of social behavior and relationships among the Japanese people. ${ }^{101}$ An independent judicially created system for dispute resolution between private parties whose legitimate interests had been injured existed, but rights of individuals were not well respected and people were expected to obey. ${ }^{102}$

Following the Tokugawa period, a time of transition known as the Meiji era (1868-1912) began. Political power was returned to the emperor and Japan struggled to maintain an independent state in the face of Western pressure to open itself to foreign influences and interests.

As a result of the lack of knowledge about Western law by Tokugawa officials, the treaties which Japan signed with Western nations were extremely prejudicial to Japan's national interests. In order to protect its independence, Japan sought to establish a system of government strong enough to discourage Western imperialism. To the Japanese, this meant rapid Westernization of Japan's legal and political systems on the model of European nations and subsequent revision of these disadvantageous treaties. ${ }^{103}$

Japan was forced to restructure its legal system to facilitate modernization of social and political organization in Japanese society and to enable it to participate in the international economic marketplace and political arena. In the Japanese frame of reference, there was simply not enough time to allow the law to spontaneously change to satisfy the demands and needs of an emerging industrial society striving to modernize itself. Japanese leaders looked to Europe for a model on which to base their new legal system. The civil law codes offered more practical advantages for a country seeking a

99. Id.

100. In China, a philosophical tradition tried to find a rational justification for inequality. "Chinese Confucianism set out to resolve the basic conflict between the need (deduced from historical experience) for a hierarchical society and the need to mitigate the injustices inherent in such an unequal order. . . In Japan the unequal relationship was made acceptable by appeal neither to religion nor to any rational theory of Staatskraft, but to claim of inherent benevolence." K. VAN Wolferen, The Enigma of Japanese Power 202 (1989).

101. Y. Noda, supra note 18 , at $35,37$.

102. H. TANAKa, supra note 95 , at 173 .

103. Id. at 199 . 
starting place than a common law system which placed so much reliance on the natural evolution of case law. ${ }^{104}$

In a manner very similar to what is taking place in China today, men, without adequate preparation or training in Western legal skills, proceeded by trial and error to pick out what they "thought was necessary from among the jumble of laws imported at random from the West and copying it uncritically." 105 These men were "imbued with the Confucian concept of law, which is diametrically opposed to the Western conception."106 Japan, like China today, lacked a consistent government policy for the establishment of a new legal system in a uniform manner. Improvisations were adopted to address immediate problems.

During the 1870's, the French Criminal and Civil Codes were translated into Japanese and an institute for the study of European culture was established. France, at this time, was viewed as having the most sophisticated and complete codification of laws. ${ }^{107}$ The Minister of Justice, Eto Shimpei, had hoped to directly apply the translated French codes to Japan.

As a judge of the Japanese Supreme Court said much later, "these translated codes were like a light shining suddenly through the dark night," and the judges of the time found in them the only legal bases on which they could properly base their decisions. Although none of the translated codes was applied in Japan as Eto had wished, these translations were the first step to the reception of Western law. ${ }^{108}$

European jurists were invited to Japan to assist in modernizing the Japanese legal system. Finally, in the early 1880's the Japanese legislature adopted Penal and Criminal Procedure Codes modeled on French law. These were the first modern legal codes adopted by Japan and remained in force until 1908 and 1890 respectively. ${ }^{109}$ Their demise coincided with the failed attempt by the Japanese legislature to adopt a French-style civil code. Opponents argued that the proposed code "did not sufficiently take account of the traditional customs and morality of the Japanese people."110 Although Japan wanted a legal system which would enable it to develop a capitalist society, some Japanese feared that French-style legal codes might have facilitated the development of a bourgeois society and possibly encouraged a French-style revolution. This group favored the formation of an absolutist state and looked toward the German legal system for guidance. ${ }^{111}$

With the adoption, in 1889 , of a constitution patterned after the Prussian monarchical constitution, German influences clearly surpassed the initially stronger influence of French law in the modernization of the Japanese legal

104. Y. NODA, supra note 18 , at 42 .

105. H. TANAKA, supra note 94 , at 194.

106. Id. at $199-200$.

107. Id. at 200. French law was taught in Japanese educational institutions and the Japanese government hired French legal instructors and advisers to teach Japanese government officials, judges, and students about French law. H. TANAKA, supra note 94, at 202-03.

108. Y. NODA, supra note 18 , at 44; H. TANAKA, supra note 94, at 202-03.

109. Y. NODA, supra note 18 , at 46.

110. Id. at 47.

111. Id. at $48-49$. 
system. What finally emerged in 1898 was a civil code modeled on European code systems including French, German, Swiss, Austrian, and Dutch legal codes. In form and substance, the Japanese were most influenced by French and German law; and, indeed, the Japanese Civil Code has been described as a selective combination of French and German legal principles. ${ }^{112}$ However, German laws were firmly establishing themselves as the dominant source of influence on Japanese legal thinking. ${ }^{13}$ A year later, the Japanese legislature adopted a German-style commercial code.

The French influence was also great in the areas of judicial organization and civil procedure. "In the first years of the Meiji era a very large number of the judges were trained according to French law, and prior to the coming into force of the Japanese codes the judges decided most cases according to French or English law."114 After the promulgation of a German-style constitution, the German influence spread to judicial organization when the Japanese legislature adopted the Law on Court Organization in 1890.115 German legal theories and interpretations then served as the basic standards of interpretation and application of Japanese law. ${ }^{116}$

Between 1870 and 1900, Japan made tremendous strides in modernizing its legal system on a European code model, mainly the French and German legal codes. However, Japanese society, as a whole, had no knowledge of these new European-style concepts of rights and duties. European legal codes were predicated on a "society in which every individual is presumed free and equal with everyone else ... and where loyal relationships are created by the exercise of an individual's free will."117 The new Japanese legal system was not meant to interfere with or to alter the actual life and morality of the Japanese people. "Even the most progressive [Japanese] intellectuals toward the end of the Edo period expressed this idea, and their motto was "western techniques, Oriental morality'."118 This philosophy as put into practice was described by Professor Yosiyuki Noda as follows:

\footnotetext{
Although Japan succeeded in faithfully and skillfully imitating the French and German legal systems, its own culture could not help but give an original character to the system that was received. The rapid Europeanization was limited to the field of state law, which dealt with only a very small section of Japanese society. Further, it must not be forgotten that the modernized law was put into operation by men whose outlook was determined by a peculiar set of geographical and historical factors. . . . For though the law can be changed from one day to the next, the men to whom it is applied and those who have to apply it in the future cannot be changed this way! Japan was destined to remain a long time subject to social rules that were quite foreign to the received law. ${ }^{119}$
}

112. Id. at 55 .

113. "From the view point of characterology," Professor Hideo Tanaka of the University of Tokyo writes, "Japanese people have an affinity for the German Geist, which values Gemuet, rather than the French esprit, which prizes precision." H. TANAKA, supra note 94, at 204.

114. Y. Noda, supra note 18 , at 53.

115. Id. at 54.

116. H. TANAKA, supra note 94 , at $196,210$.

117. Y. NodA, supra note 18 , at 58 .

118. Id. at 60 .

119. Id. at 58 . 
The end of the Tokugawa period signaled the beginning of the modern era of law in Japan. Unlike the prior law which had its origin in China, this new law was a hybrid of Western law. "[All] . . a articles of the Japanese Civil Code had their origin in modern Western law or in Roman law and not in early Japanese law." 120 However, this does not mean that early Japanese law and Confucianism has no place in the interpretation and study of the modern Japanese legal system. Culture and social habits followed for hundreds of years are deeply rooted in the lives of Japanese people.

There may be a marked difference between the modern and the old law at the level of (written) state law, but at the level of living (practice and interpretation) law there was no break in continuity. The latter evolved spontaneously and unconsciously. Historical continuity interrupted in the conscious continues in the subconscious, and this subconscious factor plays an important role in the social life of the Japanese people today. ${ }^{121}$

The Meiji era in Japan can be characterized as the Westernization of the Japanese political and legal systems. The current Westernization of the Chinese legal system resembles the Meiji era of Japanese legal development. If we look further ahead to legal developments in Japan prior to World War II, we might possibly gain some insight into future Chinese legal developments. In the Meiji era, Japan imitated European civil law and culture. During the subsequent Taisho (1912-1926) and Showa (1926-1989) periods, prior to World War II, the Japanese Government sought to cultivate a civilization which was uniquely Japanese in nature and on equal standing with European countries. ${ }^{122}$ European legal theories were foreign to the realities of Japanese society and therefore had only limited impact on the daily lives of most Japanese. ${ }^{123}$ Consequently, the imposed European-influenced legal system over time began to intersect and merge with the realities of Japanese culture and society. The resulting merger was not a mirror image of a traditional European-style civil legal system but the "natural" product of Japanese tradition and morality after "customary" or "living" law had caught up and merged with the written or "book" law. Given a moral, social, economic, cultural, and historical background different from that of Europe, the Japanese found themselves applying European legal rules and principles to factual situations and settings which were nonexistent in Europe. Westernization produced rapidly changing circumstances in Japanese society for which even customary law had no solutions. Hence, the newly created Constitution and Civil Code formed a foundation for a legal system which merged European legal theory with Japanese culture and morality (Confucianism) to begin the evolution of a unique Japanese rule of law. ${ }^{124}$ When book law and living law come into conflict, government and judges

120. Id. at 39 .

121. Id.

122. H. TANAKA, supra note 94 , at 215-16.

123. Id. at 240 .

124. "The divergence of living law from book law is a phenomenon not confined to Japan. It exists not only in codified, civil-law countries such as France and Germany, but also in common-law countries such as the United States... . The reception of Roman law in Germany, for instance, was a 
tend to adjust the law to fit policy or morality, in what is normally called interpretation of the law.

This evolutionary process of merging book law with living law was further complicated by World War II, after which a new Constitution and common law principles were introduced to and imposed on Japan. It is quite natural that these rules and principles were interpreted by Japanese jurists according to civil law theories and principles. ${ }^{125}$ Once again, book law was forced to merge with living law and the resulting product is a unique Japanese rule of law.

\section{VII}

\section{Conclusion}

The enactment of the General Principles and accompanying special statutes indicates that the current Chinese Government wants the Chinese legal system to be acceptable to the international, particularly Western, business community. These statutes have been enacted to govern business relationships between Chinese enterprises and foreign enterprises and to provide guarantees for the protection of foreign investments in China. Whether or not the General Principles can affect relationships between Chinese enterprise persons remains to be seen. The German legal concept of an enterprise person as the bearer of rights which can be transferred to another enterprise person is symbolic of a society in which activities are governed by individual decisions. ${ }^{126}$ Although such European legal concepts are included in the General Principles, Chinese law cannot be interpreted in the same manner as one might analyze European legal systems because the Chinese special statutes are socialistic in their orientation, law serves a different domestic role in China, Chinese adjust their behavior towards law differently from Europeans or Americans, Chinese courts interpret and enforce law based on expectations of the Chinese Government and citizens, and Chinese attitudes towards law have evolved from over 2000 years of Confucian tradition. Western-style law will have a significant impact in China, but we may have to wait for many years before we can begin to assess its actual impact on the Chinese legal system.

gradual process extending over several centuries, and Roman law became part of German customary law." Id. at 191 .

125. Id. at 32

126. See J. Merriman \& S. Clark, supra note 68, at 243-44. 